Boletín de la Sociedad Geológica Mexicana

VOLUMEN 68, NÚM. 2, 2016, P. 357-364

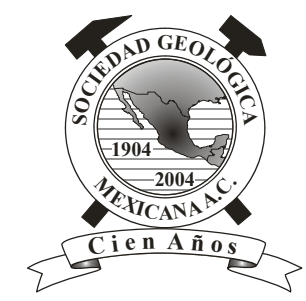

\title{
Short Note \\ Geochronology of Mexican mineral deposits. IV: the Cinco Minas epithermal deposit, Jalisco
}

\author{
Antoni Camprubí1,*, Alexander Iriondo², Margarita López-Martínez ${ }^{3}$, Aldo Ramos-Rosique ${ }^{4}$ \\ ${ }^{1}$ Instituto de Geología, Universidad Nacional Autónoma de México. Ciudad Universitaria, 04510 Coyoacán, CDMX, México. \\ ${ }^{2}$ Centro de Geociencias, Universidad Nacional Autónoma de México. Boulevard Juriquilla 3001, 76230 Querétaro, Qro., Mexico. \\ ${ }^{3}$ Centro de Investigación Científica y Educación Superior de Ensenada. Carretera Ensenada-Tijuana No. 3918, Zona Playitas, 22860 \\ Ensenada, B.C., Mexico. \\ ${ }^{4}$ Facultad de Ingeniería, Universidad Nacional Autónoma de México. Ciudad Universitaria, 04510 Coyoacán, CDMX, Mexico. \\ *Corresponding author: camprubitaga@gmail.com
}

\begin{abstract}
Two ${ }^{40} \mathrm{Ar} /{ }^{39} \mathrm{Ar}$ ages at $24.50 \pm 0.07$ and $23.46 \pm 0.26 \mathrm{Ma}$ (latest Oligocene) were obtained in this paper for adularia separates from vein material of the Cinco Minas low sulfidation epithermal deposit in Jalisco, southwestern Mexico. Such ages confirm the migration of metallogenic activity along with volcanism as the Sierra Madre Occidental migrated southwards since the latest Oligocene and into the Miocene. These deposits are synchronous to andesitic volcanism nearby. In addition, these ages indicate the occurrence of epithermal mineralization prior to the climactic event of ignimbrite flare-up in the Miocene. This makes necessary to refine previous ideas in the metallogeny of southwestern Mexico, which suggested a scenario in which the formation of epithermal and other types of hydrothermal deposits in the region were produced almost exclusively as a result of the early Miocene peak episode of volcanism.
\end{abstract}

Keywords: Cinco Minas, Mexico, epithermal deposits, low sulfidation, ${ }^{40} \mathrm{Ar} /{ }^{39} \mathrm{Ar}$ ages, adularia.

\section{Resumen}

En el presente trabajo se obtuvieron dos edades de ${ }^{40} \mathrm{Ar}{ }^{\beta^{9}} \mathrm{Ar}$ en $24.50 \pm 0.07$ y $23.46 \pm 0.26 \mathrm{Ma}$ (Oligoceno terminal) en adularia separada de material en vetas del depósito epitermal de baja sulfuración de Cinco Minas en Jalisco, México suroccidental. Tales edades confirman la migración de la actividad metalogenética en conjunto con el volcanismo a medida que la Sierra Madre Occidental migró en dirección sur desde el Oligoceno terminal hacia el Mioceno. Estos depósitos son sincrónicos al volcanismo andesítico en sus inmediaciones. Adicionalmente, estas edades indican la presencia de mineralizaciones epitermales con anterioridad al evento climático del volcanismo ignimbrítico del Mioceno. Ello obliga a refinar las ideas preexistentes sobre la metalogenia de la porción suroccidental de México, que sugieren un contexto en que la formación de depósitos epitermales, y los de otras tipologías de origen hidrotermal en la región, fueron producidos de forma casi exclusiva como resultado del episodio más intenso de volcanismo del Mioceno temprano.

Palabras clave: Cinco Minas, México, depósitos epitermales, sulfuración baja, edades ${ }^{40} \mathrm{Ar}{ }^{\beta 9} \mathrm{Ar}$, adularia. 


\section{Introduction}

Southwestern Mexico, especially in and around the state of Nayarit (Figure 1), is a highly prospective region for epithermal deposits (Aguilar-Nogales, 1987a,b; Camprubí et al., 2003; Camprubí and Albinson, 2006, 2007; Camprubí, 2013), either Au-Ag or polymetallic deposits, which are likely to correspond to dominantly low or intermediate sulfidation deposits, respectively. The Cinco Minas district is located in the north-central part of the state of Jalisco (Figure 1), and contains Au-Ag low sufidation epithermal vein deposits albeit little significant geological or economical information is available for ore deposits in this region (e.g., Aguilar-Nogales, 1987a,b; Consejo de Recursos Minerales, 1992; Servicio Geológico Mexicano, 2006a,b). The epithermal veins of the Cinco Minas district occur in the vicinities of the regional-scale Cinco Minas normal fault (Servicio Geológico Mexicano, 2006a,b). This fault was considered to be latest Miocene to early Pliocene in age by Ferrari and Rosas-Elguera (2000), and found in the northwestern part of the Plan de Barrancas-Santa Rosa graben, the latter being a part of the Tepic-Zacoalco rift. The epithermal veins are hosted by early Miocene ignimbrites and andesites of the Sierra Madre Occidental, that were dated by means of $\mathrm{K}-\mathrm{Ar}$, thus yielding ages at $24.7 \pm 0.6$,
$22.5 \pm 0.4$, and 20.2 $\pm 0.5 \mathrm{Ma}$ (Nieto-Obregón et al., 1985). These rocks were intruded by a granodioritic body, which is well exposed in the Santo Domingo village and was dated at $19.5 \pm 0.5 \mathrm{Ma}$ (Nieto-Obregón et al., 1985). These ages are consistent with the Miocene metallogenic episode in the southern portion of the Sierra Madre Occidental silicic large igneous province (SLIP) in association with its last ignimbrite flare-up (Camprubí et al., 2003; Ferrari et al., 2005, 2007; Camprubí and Albinson, 2006, 2007; Camprubí, 2013, and references therein). Camprubí et al. (2003) interpreted that epithermal deposits in the Cinco Minas area would be related to the intrusive at Santo Domingo, which would therefore confer to these deposits ages younger than 19.5 Ma.

Miocene ages were deduced (Camprubí et al., 2003) for several epithermal deposits, and a few tin vein deposits associated with fluorine-rich rhyolites, in the region shown in Figure 1. However, the vast majority of these deposits remain undated; that, notwithstanding that these deposits constitute the last mineralized area and metallogenic epoch associated with the evolution of the Sierra Madre Occidental SLIP (Camprubí, 2013). Such was the case of the epithermal deposits at Cinco Minas, for which we present the first age determinations in this paper.

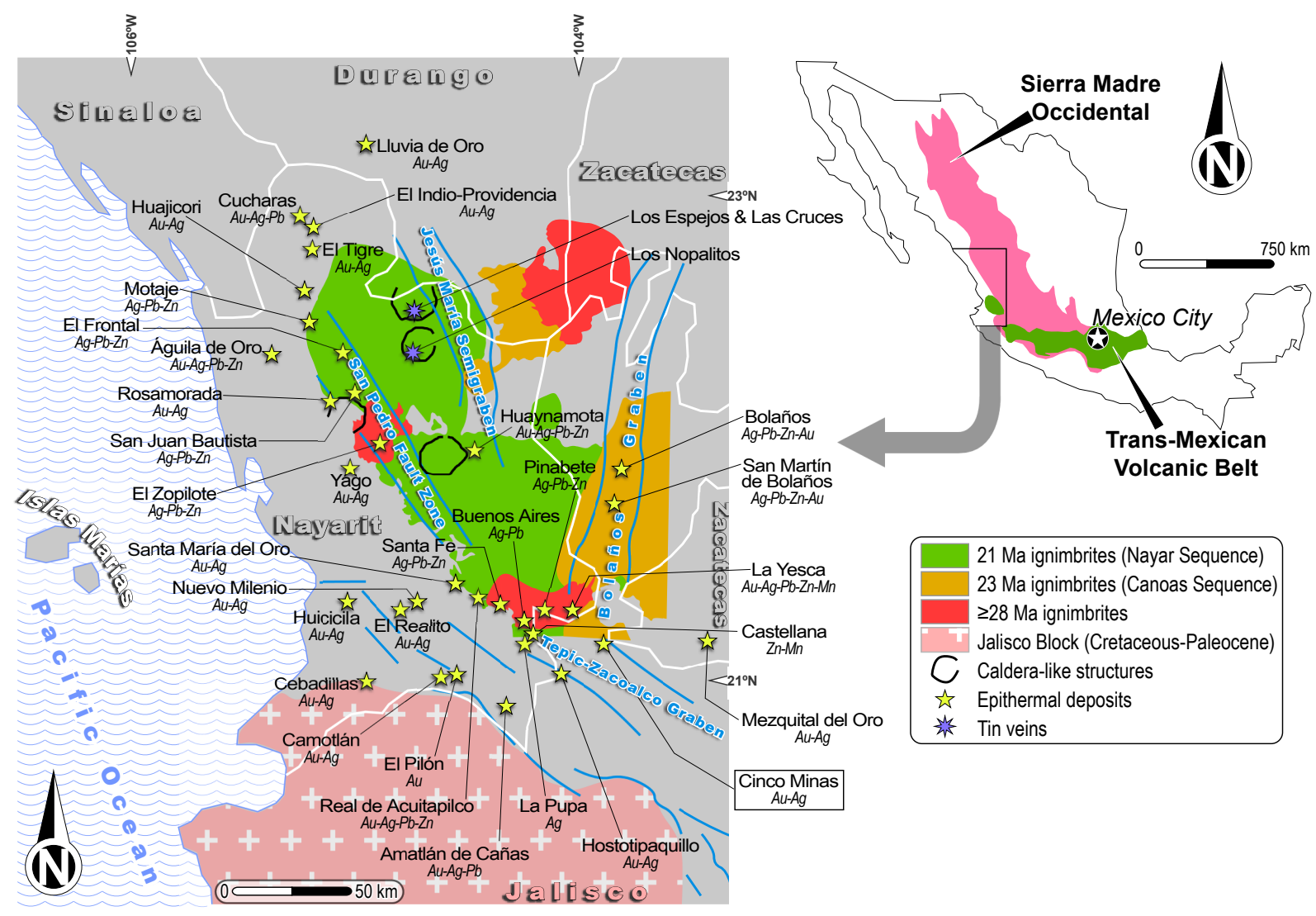

Figure 1. Geographic distribution of ore deposits of possible latest Oligocene to Miocene age in southwestern Mexico (modified from Camprubí, 2013). 


\section{Methods and results}

Pure mineral separates of adularia from crustiform vein material (mostly quartz; Figure 2) from the Cinco Minas district were dated by ${ }^{40} \mathrm{Ar}{ }^{39} \mathrm{Ar}$ geochronology (Figures 3 and 4 , and Tables 1 and 2). Adularia grains that ranged in size from 250 to $180 \mu \mathrm{m}$ were obtained by crushing and were separated using heavy liquids and hand picking to a purity of $>99 \%$. The samples were washed in acetone, alcohol, and deionized water in an ultrasonic cleaner to remove dust and then re-sieved by hand using a $180-\mu \mathrm{m}$ sieve. Aliquots of these samples were analyzed in two separate laboratories.

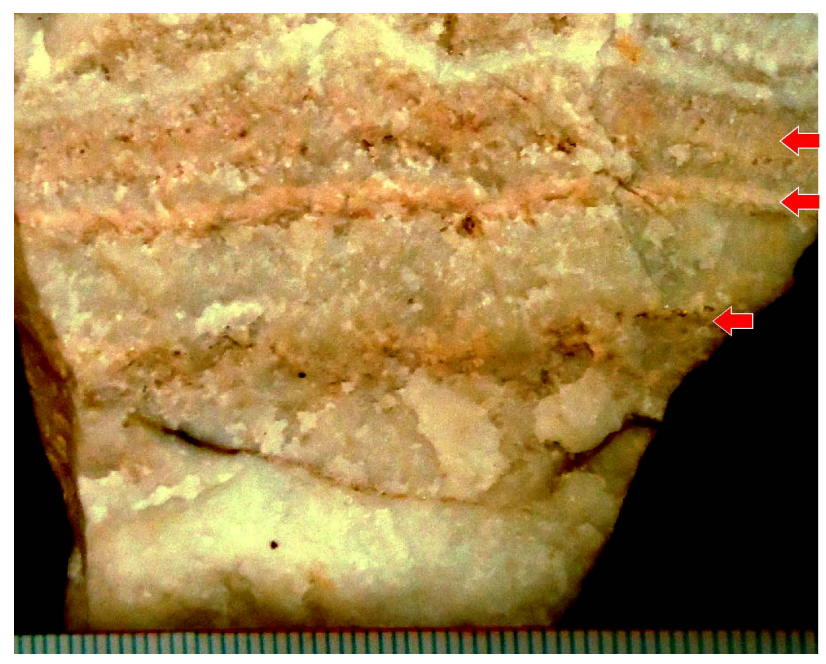

Figure 2. Alternated crustiform silica and adularia bands (the latter, rose bands indicated by red arrows) of low sulfidation epithermal veins of the Cinco Minas district. Adularia from the middle band corresponds to sample 5M-1.

\subsection{Procedure and results in laboratory 1}

Aliquots of the adularia sample 5M-1 (1.82 mg) were packaged in copper capsules and sealed under vacuum in quartz tubes. The sample aliquots were then irradiated in package number KD53 for 20 hours in the central thimble facility at the TRIGA reactor (GSTR) at the U.S. Geological Survey in Denver, Colorado. The monitor mineral used in the package was Fish Canyon Tuff sanidine (FCT-3) with an age of $27.79 \mathrm{Ma}$ (Kunk et al., 1985; Cebula et al., 1986) relative to MMhb-1 with an age of $519.4 \pm 2.5 \mathrm{Ma}$ (Alexander et al., 1978; Dalrymple et al., 1981). The type of container and the geometry of the sample and standards were similar to that described by Snee et al. (1988).

The adularia sample was analyzed at the U.S. Geological Survey Thermochronology lab in Denver, Colorado, using the ${ }^{40} \mathrm{Ar} /{ }^{39} \mathrm{Ar}$ step-heating method and a MAP 216 mass spectrometer fitted with an electron multiplier. For additional information on the analytical procedure see Kunk et al. (2001).

The ${ }^{40} \mathrm{Ar} /{ }^{39} \mathrm{Ar}$ results are listed in Table 1 and presented in Figure 3. The analyzed sample yielded a plateau age at $24.50 \pm 0.07 \mathrm{Ma}$, which is supported, within analytical error, by the less precise isochron age calculated at 24.47 $\pm 0.17 \mathrm{Ma}$.

\subsection{Procedure and results in laboratory 2}

The ${ }^{40} \mathrm{Ar} /{ }^{39} \mathrm{Ar}$ analyses were performed at the Geochronology Laboratory of the Departmento de Geología, Centro de Investigación Científica y Educación Superior de Ensenada (CICESE, Mexico). The argon isotope experiments were conducted on fragments separated
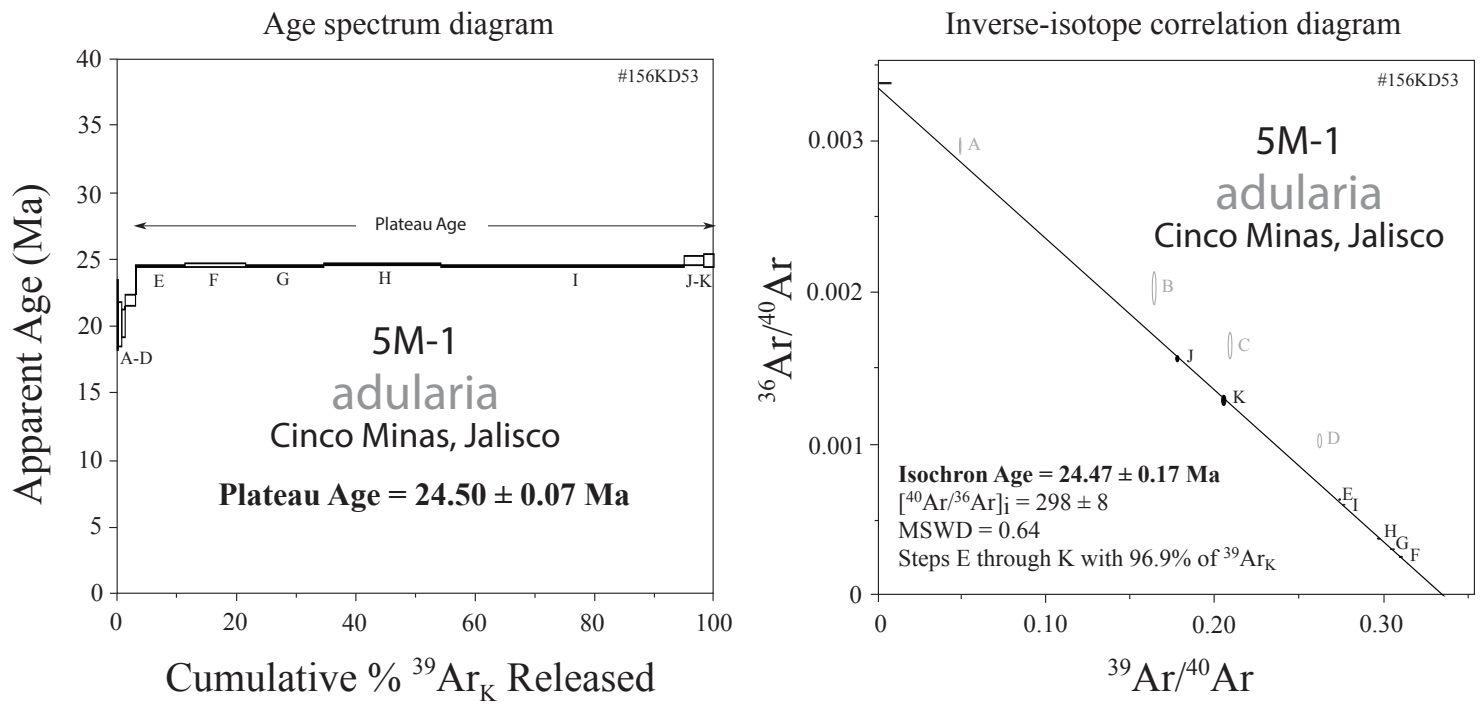

Figure $3 .{ }^{40} \mathrm{Ar} /{ }^{39} \mathrm{Ar}$ age spectrum and isochron for the $5 \mathrm{M}-1$ adularia sample from low sulfidation epithermal veins of the Cinco Minas district (USGS laboratory). 


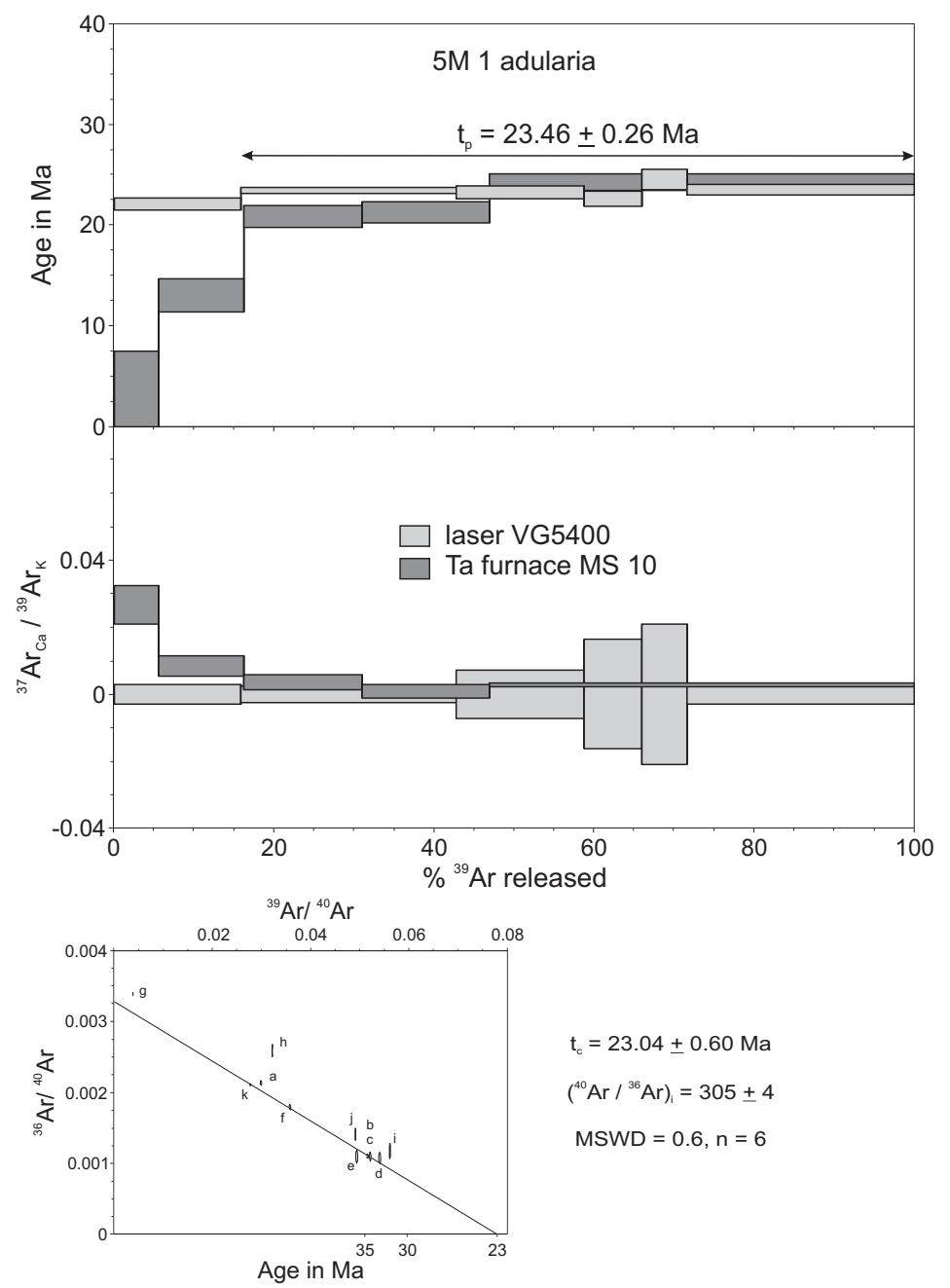

Figure $4 .{ }^{40} \mathrm{Ar} /{ }^{39} \mathrm{Ar}$ age spectrum and isochron for the $5 \mathrm{M}-1$ adularia sample from low sulfidation epithermal veins of the Cinco Minas district (USGS laboratory).

Table $1 .{ }^{40} \mathrm{Ar} /{ }^{39} \mathrm{Ar}$ step-heating data for an adularia sample of the epithermal veins at the Cinco Minas district, Jalisco (USGS lab).

\begin{tabular}{|c|c|c|c|c|c|c|c|c|c|}
\hline Step & $\begin{array}{c}\text { Temp. } \\
{ }^{\circ} \mathrm{C}\end{array}$ & $\begin{array}{l}\%^{39} \mathrm{Ar} \\
\text { of total } \\
\end{array}$ & $\begin{array}{c}\text { Radiogenic } \\
\text { Yield (\%) }\end{array}$ & $\begin{array}{c}{ }^{39} \mathrm{Ar}_{\mathrm{k}} \\
\text { (moles) }\end{array}$ & ${ }^{40} \underline{\mathrm{Ar}^{*}}$ & $\begin{array}{c}\text { Apparent } \\
\mathrm{K} / \mathrm{Ca} \\
\end{array}$ & $\begin{array}{c}\text { Apparent } \\
\mathrm{K} / \mathrm{Cl} \\
\end{array}$ & $\begin{array}{l}\text { Apparent } \\
\text { Age (Ma) }\end{array}$ & $\begin{array}{l}\text { Erro1 } \\
(\mathrm{Ma}) \\
\end{array}$ \\
\hline $5 M-1$ & Adularia & $J=0.004588$ & $w t=$ & \#15 & & & & & \\
\hline A & 700 & 0.4 & 12.4 & $1.06 \mathrm{E}-16$ & 2.519 & 1 & 47 & 20.73 & \pm 2.64 \\
\hline B & 750 & 0.4 & 40.1 & $1.26 \mathrm{E}-16$ & 2.441 & 2 & 99 & 20.09 & \pm 1.62 \\
\hline $\mathrm{C}$ & 800 & 0.7 & 51.3 & $1.97 \mathrm{E}-16$ & 2.452 & 3 & 115 & 20.18 & \pm 1.03 \\
\hline $\mathrm{D}$ & 900 & 1.6 & 69.8 & $4.69 \mathrm{E}-16$ & 2.659 & 14 & 167 & 21.88 & \pm 0.43 \\
\hline $\mathbf{E}$ & 1000 & 8.5 & 81.5 & $2.46 \mathrm{E}-15$ & 2.972 & 69 & 654 & 24.44 & \pm 0.11 \\
\hline $\mathbf{F}$ & 1100 & 10.1 & 92.6 & $2.95 \mathrm{E}-15$ & 2.980 & 40 & 1299 & 24.50 & $\pm \mathbf{0 . 0 8}$ \\
\hline $\mathbf{G}$ & 1200 & 13.1 & 91.0 & $3.85 \mathrm{E}-15$ & 2.976 & 79 & 1282 & 24.47 & $\pm \mathbf{0 . 0 7}$ \\
\hline $\mathbf{H}$ & 1300 & 19.6 & 88.9 & $5.71 \mathrm{E}-15$ & 2.990 & 89 & 158 & 24.58 & \pm 0.06 \\
\hline I & 1400 & 40.7 & 82.4 & $1.18 \mathrm{E}-14$ & 2.977 & 62 & 917 & 24.48 & \pm 0.06 \\
\hline $\mathbf{J}$ & 1500 & 3.3 & 53.9 & $9.81 \mathrm{E}-16$ & 3.018 & 28 & 124 & 24.81 & $\pm \mathbf{0 . 3 0}$ \\
\hline $\mathbf{K}$ & 1650 & 1.6 & 62.1 & 4.63E-16 & 3.016 & 4 & 307 & 24.79 & \pm 0.47 \\
\hline \multicolumn{2}{|c|}{ Total Gas } & 100 & 83.6 & $2.91 \mathrm{E}-14$ & 2.969 & 64 & 772 & 24.41 & \\
\hline & & \multicolumn{4}{|c|}{$96.9 \%$ of gas on plateau in 1000 through $1650^{\circ} \mathrm{C}$ steps } & \multicolumn{2}{|c|}{ Plateau Age $=$} & 24.50 & \pm 0.07 \\
\hline
\end{tabular}

Ages calculated assuming an initial ${ }^{40} \mathrm{Ar} /{ }^{36} \mathrm{Ar}=295.5 \pm 0$.

All precision estimates are at the one sigma level of precision.

Ages of individual steps do not include error in the irradiation parameter J.

No error is calculated for the total gas age. 
Table 2. ${ }^{40} \mathrm{Ar} /{ }^{39} \mathrm{Ar}$ step-heating data for an adularia sample of the epithermal veins at the Cinco Minas district, Jalisco (CICESE lab).

\begin{tabular}{|c|c|c|c|c|c|c|c|c|c|c|c|}
\hline Pwr & ${ }^{39} \mathrm{Ar} \times 10^{-6}$ & $\%{ }^{39} \mathrm{Ar}$ & ${ }^{40} \mathrm{Ar}^{*} \%^{39} \mathrm{Ar}_{\mathrm{K}}$ & $1 \sigma$ & Age in Ma & $1 \sigma$ & & & $\%{ }^{40} \mathrm{Ar}^{*}$ & ${ }^{40} \mathrm{Ar} /{ }^{36} \mathrm{Ar}$ & ${ }^{37} \mathrm{Ar}_{\mathrm{Ca}}{ }^{39} \mathrm{Ar}_{\mathrm{K}}$ \\
\hline 3 & 170.068 & 15.89 & 3.55 & 0.1 & 22.16 & 0.6 & $\mathrm{a}$ & $\$$ & 36.93 & 468.56 & $<0.001$ \\
\hline 6 & 288.428 & 26.94 & 3.76 & 0.05 & 23.47 & 0.31 & $\mathrm{~b}$ & & 67.53 & 910.18 & $<0.001$ \\
\hline 8 & 170.93 & 15.97 & 3.73 & 0.1 & 23.28 & 0.65 & $\mathrm{c}$ & & 67.66 & 913.76 & $<0.001$ \\
\hline 10 & 77.055 & 7.2 & 3.63 & 0.12 & 22.66 & 0.78 & d & & 68.3 & 932.25 & $<0.001$ \\
\hline 13 & 60.285 & 5.63 & 3.93 & 0.16 & 24.55 & 1.02 & e & & 67.62 & 912.7 & $<0.001$ \\
\hline 13.5 & 303.723 & 28.37 & 3.77 & 0.09 & 23.56 & 0.55 & $\mathrm{f}$ & & 47.04 & 557.95 & $<0.001$ \\
\hline
\end{tabular}

Integrated results

\begin{tabular}{|c|c|c|c|c|c|c|c|c|c|c|c|}
\hline${ }^{39} \mathrm{Ar} \times 10^{-6}$ & ${ }^{40} \mathrm{Ar}^{*}{ }^{39} \mathrm{Ar}_{\mathrm{K}}$ & $1 \sigma$ & Age in Ma & $1 \sigma$ & $\%{ }^{40} \mathrm{Ar}^{*}$ & ${ }^{40} \mathrm{Ar}{ }^{36} \mathrm{Ar}$ & ${ }^{37} \mathrm{Ar}_{\mathrm{Ca}}{ }^{39} \mathrm{Ar}_{\mathrm{K}}$ & & & & \\
\hline 1070 & 3.72 & 0.04 & 23.26 & 0.28 & 54.05 & 643.133 & $<0.001$ & & & & \\
\hline CIC 72R & $\mathrm{J}=0.003485 \pm 0$ & 0018 & & & & & & & & & \\
\hline \multicolumn{12}{|c|}{ Preferred age $t_{p}=23.46 \pm 0.26 \mathrm{Ma}$} \\
\hline \multicolumn{12}{|c|}{ Weighted mean of fractions b to $\mathrm{f}$, representing $84.11 \%$ of ${ }^{39} \mathrm{Ar}$ released in 5 consecutive fractions, MSWD $=0.6$} \\
\hline \multicolumn{12}{|c|}{ MS-10 temperature controlled step-heating experiments } \\
\hline Temp & ${ }^{39} \mathrm{Ar} \mathrm{cc} \mathrm{STP} / \mathrm{g}$ & $\%{ }^{39} \mathrm{Ar}$ & ${ }^{40} \mathrm{Ar}^{*}{ }^{39} \mathrm{Ar}_{\mathrm{K}}$ & $1 \sigma$ & Age in $\mathrm{Ma}$ & $1 \sigma$ & & & $\%{ }^{40} \mathrm{Ar}^{*}$ & ${ }^{40} \mathrm{Ar} /{ }^{36} \mathrm{Ar}$ & ${ }^{37} \mathrm{Ar}_{\mathrm{Ca}}{ }^{39} \mathrm{Ar}_{\mathrm{K}}$ \\
\hline 700 & $5.12 \mathrm{E}-08$ & 5.63 & -0.17 & 1.38 & -1.04 & 8.52 & $\mathrm{~g}$ & $\$$ & -0.22 & 294.84 & 0.027 \\
\hline 900 & $1.35 \mathrm{E}-07$ & 14.8 & 3.42 & 0.18 & 20.9 & 1.09 & $\mathrm{i}$ & $\$$ & 65.39 & 853.72 & 0.004 \\
\hline 1000 & $1.45 \mathrm{E}-07$ & 15.93 & 3.48 & 0.17 & 21.31 & 1.04 & $\mathrm{j}$ & $\$$ & 58.34 & 709.3 & 0.001 \\
\hline 1350 & $4.82 \mathrm{E}-07$ & 53.03 & 3.98 & 0.14 & 24.33 & 0.85 & $\mathrm{k}$ & & 37.64 & 473.89 & 0.003 \\
\hline
\end{tabular}

Integrated results

\begin{tabular}{ccccccccc} 
weight & ${ }^{39} \mathrm{Arcc} \mathrm{STP} / \mathrm{g}$ & ${ }^{40} \mathrm{Ar}^{*} /^{39} \mathrm{Ar}_{\mathrm{K}}$ & $1 \sigma$ & Age in Ma & $1 \sigma$ & ${ }^{40} \mathrm{Ar}^{*}$ & ${ }^{40} \mathrm{Ar}^{36} \mathrm{Ar}$ & ${ }^{37} \mathrm{Ar}_{\mathrm{Ca}}{ }^{39} \mathrm{Ar}_{\mathrm{K}}$ \\
\hline 0.197 & $9.09 \mathrm{E}-07$ & 3.39 & 0.18 & 20.73 & 1.36 & 27 & 404.767 & 0.005 \\
\hline CIC 72B & $\mathrm{J}=0.003412 \pm 0.000131$ & & & &
\end{tabular}

$\mathrm{t}_{\mathrm{c}}=23.04 \pm 0.60 \mathrm{Ma} ;\left({ }^{40} \mathrm{Ar}{ }^{36} \mathrm{Ar}\right)_{\mathrm{i}}=305 \pm 4, \mathrm{MSWD}=0.6$ for $\mathrm{n}=6$

$\$$ fraction ignored in the isochron given in the figure

from sample 5M-1. The mineral grains were heated, in two different experiments, with a MS-10 Ta furnace and with a Coherent Ar-ion Innova 370 laser. The extraction system is on line with a VG5400 mass spectrometer. The sample and irradiation monitors, were irradiated in the U-enriched research reactor of University of McMaster in Hamilton, Canada, at position 5C. To block thermal neutrons, the capsule was covered with a cadmium liner during irradiation. To determine the neutron flux variations, aliquots of the irradiation monitor FCT sanidine (28.201 \pm 0.046 Ma; Kuiper et al., 2008) were irradiated alongside sample 5M-1. Upon irradiation the monitors were fused in one step while the adularia sample $5 \mathrm{M}-1$ was stepheated. The argon isotopes were corrected for blank, mass discrimination, radioactive decay of ${ }^{37} \mathrm{Ar}$ and ${ }^{39} \mathrm{Ar}$ and atmospheric contamination. For the Ca neutron interference reactions, the factors given by Masliwec (1984) were used. The decay constants recommended by Steiger and Jäger (1977) were applied in the data processing. The equations reported by York et al. (2004) were used in all the straight line fitting routines of the argon data reduction. The relevant ${ }^{40} \mathrm{Ar} /{ }^{39} \mathrm{Ar}$ data are presented in Table 2, which includes the results of the individual steps, and the integrated, plateau and isochron ages. The analytical precision is reported as one standard deviation $(1 \sigma)$. The error in the integrated, plateau and isochron ages includes the scatter in the irradiation monitors.

The ${ }^{40} \mathrm{Ar} /{ }^{39} \mathrm{Ar}$ results are listed in Table 2 and presented in Figure 4. The analyzed sample yielded a plateau age at $23.46 \pm 0.26 \mathrm{Ma}$.

\section{Discussion and conclusions}

There is a slight discrepancy in the ${ }^{40} \mathrm{Ar} /{ }^{39} \mathrm{Ar}$ ages from laboratories 1 and 2: $24.50 \pm 0.07$ vs. $23.46 \pm 0.26 \mathrm{Ma}$, respectively (both corresponding to the latest Oligocene). This can be explained by the different temperature ranges used in the experiments: those using a MS-10 Ta furnace in laboratory 2 (CICESE) attained $1350{ }^{\circ} \mathrm{C}$, whereas those in laboratory 1 (USGS) attained $1600{ }^{\circ} \mathrm{C}$, and there was no sound temperature control on laser experiments in laboratory 2. In addition, the amount of ${ }^{39} \mathrm{Ar}$ released behaved differently in these experiments: 40\% was released at $1400{ }^{\circ} \mathrm{C}$ in laboratory 1 (USGS), whereas $\sim 53 \%$ was released at $1350{ }^{\circ} \mathrm{C}$ using the Ta furnace in laboratory 2 (CICESE). In addition, such different behavior may be attributed to having used different reactors and conditions for irradiation. All the same, both can be essentially considered as the same age.

The ages obtained in this study confirm the southward migration of metallogenic activity along with volcanism in the Sierra Madre Occidental (SMO) silicic large igneous province (SLIP), as indicated by Camprubí et al. (2003). However, the present study suggests that the formation of epithermal deposits in southwestern Mexico, which followed the last flare-up of the SMO (Ferrari et al., 2005, 2007), started in the latest Oligocene instead of the Miocene; that is, before volcanic activity of the SMO in southwestern Mexico peaked. This makes necessary to undertake further high-resolution geochronological determinations in hydrothermal minerals for epithermal and tin vein deposits 
in this region, in order to refine their plausible ages, as these are commonly acknowledged as Miocene alone (see Table 3; Aguilar-Nogales, 1987a,b; Camprubí et al., 2003; Camprubí, 2013).

Some latest Oligocene to Miocene (dated at $24.7 \pm 0.6$, $22.5 \pm 0.4,20.2 \pm 0.5$, and $19.5 \pm 0.5 \mathrm{Ma}$; Nieto-Obregón et al., 1985) ignimbrite, andesite and granodiorite units in the study area were initially regarded as to represent the likeliest volcanic rocks to be associated with the formation of epithermal deposits (Camprubí et al., 2003). Some of these rocks, however, are too young to be plausibly associated with epithermal mineralization. That is the case even for those rocks with latest Oligocene ages (24.7 \pm $0.6 \mathrm{Ma}$ ), provided that no intermediate to low sulfidation deposits in Mexico have been found to form less than 2 m.yr. after the emplacement of the youngest volcanic or hypabyssal rocks (see discussion in Martínez-Reyes et al., 2015). Such latest Oligocene ages for volcanic units in the neighboring regions suggest a strong link between epithermal mineralization and volcanism nonetheless. Also, it remains to be reexamined the role of the regional-scale Cinco Minas normal fault in ruling the emplacement of epithermal deposits, as its attributed age (latest Miocene to early Pliocene; Ferrari and Rosas-Elguera, 2000) is significantly younger than the ages for epithermal deposits in this study. Then, it follows that either the Cinco Minas normal fault is older than initially thought or that it played no significant role in the emplacement of epithermal deposits.

Table 3. Ages of epithermal deposits in the Cinco Minas district obtained for this study, and relevant ages for other hydrothermal deposits in the region shown in Figure 1, between the latest Oligocene and the Miocene.

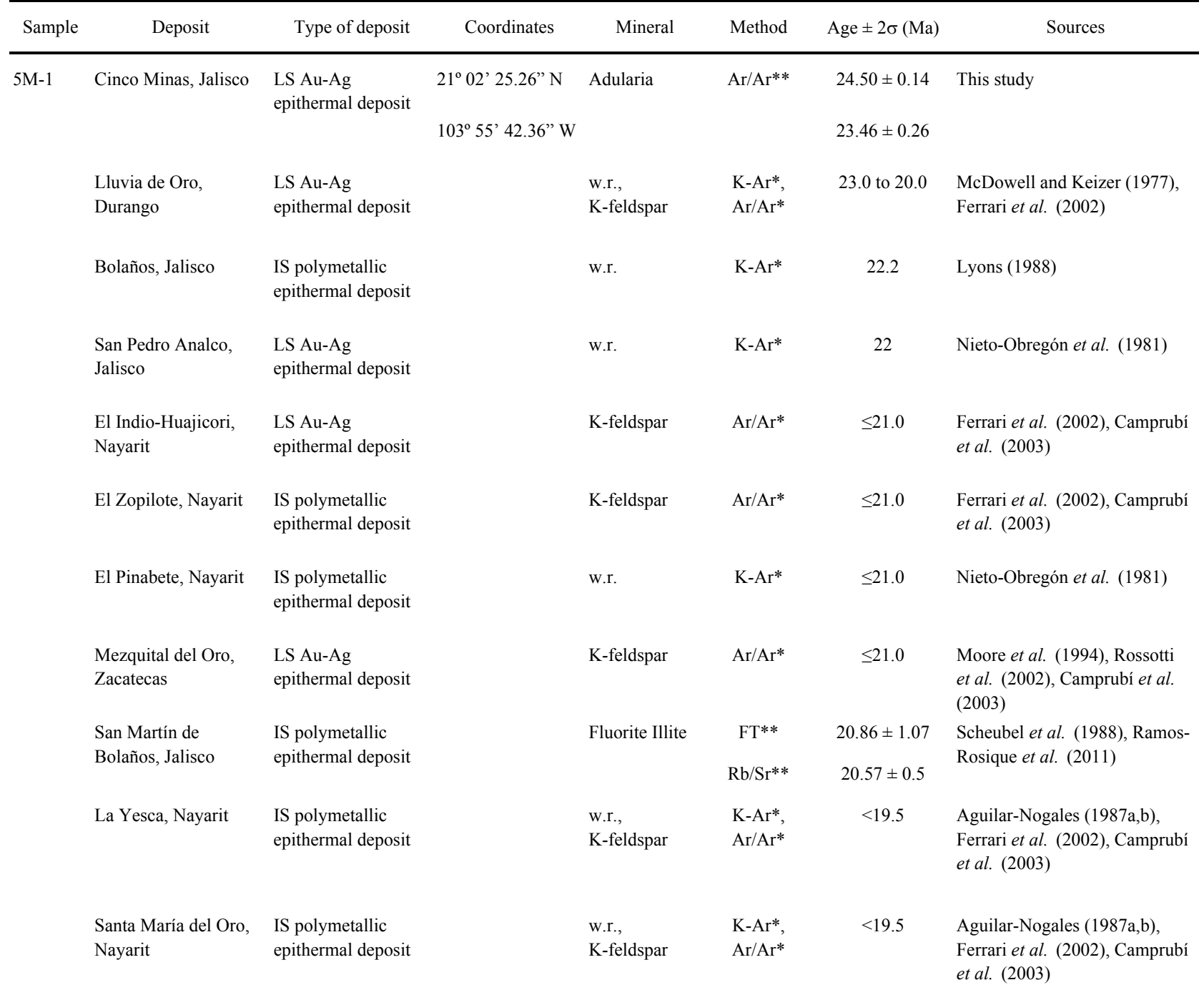

Notes: Besides the deposits consigned in this table, Camprubí (2013) also speculated about similar ages for other epithermal deposits, and tin veins in association with F-rich rhyolitic rocks. Asterisks $(*)$ denote analyses performed on host rocks, and double asterisks $(* *)$ denote analyses performed on minerals within hydrothermal associations. Key: FT = fission tracks; IS = intermediate sulfidation; LS = low sulfidation; w.r. $=$ whole rock. 


\section{Acknowledgements}

This study was financed by means of CONACYT grant number 155662. The authors wish to thank Michael Kunk for providing access and guidance to perform the ${ }^{40} \mathrm{Ar} /{ }^{39} \mathrm{Ar}$ geochronology studies at the U.S. Geological Survey Thermochronology Lab in Denver, Colorado. We thank M.A. García-García for his assistance in the ${ }^{40} \mathrm{Ar} /{ }^{39} \mathrm{Ar}$ experiments, for which A.S. Rosas-Montoya was in charge of the mineral separation and preparation of the analyzed samples at the CICESE. Kind assistance was provided during fieldwork by Luca Ferrari and Andy Rankin, in addition to their fruitful comments. The age determinations in this study were first mentioned by Camprubí (2013).

\section{References}

Aguilar-Nogales, M., 1987a, Volcanismo continuo y yacimientos miocénicos en Nayarit, in Memoria XVII Convención Nacional AIMMGM: México, D.F., Asociación de Ingenieros de Minas, Metalurgistas y Geólogos de México (AIMMGM), 114-125.

Aguilar-Nogales, M., 1987b, La Yesca, un yacimiento manganoargentífero con posibilidades de aprovechamiento: Pachuca, Hidalgo, Consejo de Recursos Minerales, unpublished report.

Alexander, E.C. Jr., Mickelson, G.M., Lanphere, M.A., 1978, Mmhb1: a new ${ }^{40} \mathrm{Ar} /{ }^{39} \mathrm{Ar}$ dating standard, in Zartman, R.E. (ed.), Short papers of the fourth international conference, geochronology, cosmochronology, and isotope geology: U.S. Geological Survey Open-File Report, 78-701, 6-8.

Camprubí, A., 2013, Tectonic and metallogenic history of Mexico, in Colpron, M., Bissig, T., Rusk, B.G., Thompson, J.F.H., (eds.), Tectonics, metallogeny, and discovery: the North American Cordillera and similar accretionary settings: Society of Economic Geologists, Special Publication, 17, 201-243.

Camprubí, A., Albinson, T., 2006, Depósitos epitermales en México: actualización de su conocimiento y reclasificación empírica: Boletín de la Sociedad Geológica Mexicana, 58 (1), 27-81.

Camprubí, A., Albinson, T., 2007, Epithermal deposits in México - an update of current knowledge, and an empirical reclassification, in Alaniz-Álvarez, S.A., Nieto-Samaniego, A.F. (eds.), Geology of México: Celebrating the Centenary of the Geological Society of México: The Geological Society of America Special Paper, 422, 377-415.

Camprubí, A., Ferrari, L., Cosca, M.A., Cardellach, E., Canals, À., 2003, Ages of epithermal deposits in Mexico: regional significance and links with the evolution of Tertiary volcanism: Economic Geology, 98, 1029-1037.

Cebula, G.T., Kunk, M.J., Mehnert, H.H., Naeser, C.W., Obradovich, J.D., Sutter, J.F., 1986, The Fish Canyon Tuff: A potential standard for the ${ }^{40} \mathrm{Ar}{ }^{39} \mathrm{Ar}$ and fission track dating methods: Terra Cognita, 6, 140.

Consejo de Recursos Minerales, 1992, Geological-mining monograph of the state of Jalisco: Pachuca, Hidalgo, Consejo de Recursos Minerales, $122 \mathrm{p}$.

Dalr ymple, G.B., Alexander, E.C., Lanphere, M.A., Kraker, G.P., 1981, Irradiation of samples for ${ }^{40} \mathrm{Ar} /{ }^{39} \mathrm{Ar}$ dating using the Geological Survey TRIGA reactor: U.S. Geological Survey Professional Paper, $1176,55 \mathrm{p}$.

Ferrari, L., Rosas-Elguera, J., 2000, Late Miocene to Quaternary extension at the northern boundary of the Jalisco block, western Mexico: the Tepic-Zacoalco rift revised: Geological Society of America Special Paper, 334, 41-64.
Ferrari, L., López-Martínez, M., Rosas-Elguera, J., 2002, Ignimbrite flare up and deformation in the southern Sierra Madre Occidental, western Mexico: Implications for the late subduction history of the Farallon plate: Tectonics, 21, 1-24.

Ferrari, L., Valencia-Moreno, M., Bryan, S., 2005, Magmatismo y tectónica en la Sierra Madre Occidental y su relación con la evolución de la margen occidental de Norteamérica: Boletín de la Sociedad Geológica Mexicana, 57, 343-378.

Ferrari, L., Valencia-Moreno, M., Bryan, S., 2007, Magmatism and tectonics of the Sierra Madre Occidental and its relation with the evolution of the western margin of North America, in AlanizÁlvarez, S.A., and Nieto-Samaniego, Á.F., (eds.), Geology of México: Celebrating the Centenary of the Geological Society of México: Geological Society of America Special Paper, 422, 1-39.

Kuiper, K.F., Deino, A., Hilgen, F.J., Krijgsman, W., Renne, P.R., Wijbrans, J.R., 2008. Synchronizing rock clocks of Earth history: Science, 320, 500-504.

Kunk, M.J., Sutter, J.F., Naeser, C.W., 1985, High-precision ${ }^{40} \mathrm{Ar} /{ }^{39} \mathrm{Ar}$ ages of sanidine, biotite, hornblende, and plagioclase from the Fish Canyon tuff, San Juan volcanic field, South-central Colorado [abs.]: Geological Society of America Abstracts with Programs, 17, 636.

Kunk, M.J., Winick, J.A., Stanley, J.O., 2001, ${ }^{40} \mathrm{Ar} /{ }^{39} \mathrm{Ar}$ age-spectrum and laser fusion data for volcanic rocks in west central Colorado: U.S. Geological Survey Open-File Report, 01-472, 94 p.

Lyons, J.I., 1988, Geology and ore deposits of the Bolaños silver district, Jalisco, Mexico: Economic Geology, 83, 1560-1582.

Martínez-Reyes, J.J., Camprubí, A., Uysal, I.T., Iriondo, A., GonzálezPartida, E., 2015, Geochronology of Mexican mineral deposits I: Veta Madre and Sierra epithermal vein systems, Guanajuato district: Boletín de la Sociedad Geológica Mexicana, in press.

Masliwec, A., 1984, Applicability of the ${ }^{40} \mathrm{Ar} /{ }^{39} \mathrm{Ar}$ method to the dating of ore bodies: Unpublished $\mathrm{PhD}$ Dissertation. University of Toronto, Toronto, Ontario, Canada.

McDowell, F.W., Keizer, R.P., 1977, Timing of mid-Tertiary volcanism in the Sierra Madre Occidental between Durango city and Mazatlan, Mexico: Geological Society of America Bulletin, 88, 1479-1487.

Moore, G., Marone, C., Carmichael, I.S.E., Renne, P., 1994, Basaltic volcanism and extension near the intersection of the Sierra Madre volcanic province and the Mexican volcanic belt: Geological Society of America Bulletin, 106, 383-394.

Nieto-Obregón, J., Delgado-Argote, L.A., Damon, P.E., 1981, Relaciones petrológicas y geocronológicas del magmatismo de la Sierra Madre Occidental y el Eje Neovolcánico en Nayarit, Jalisco y Zacatecas, in Memoria XIV Convención Nacional AIMMGM: México, D.F., Asociación de Ingenieros de Minas, Metalurgistas y Geólogos de México, 327-361.

Nieto-Obregón, J., Delgado-Argote, L., Damon, P.E., 1985, Geochronologic, petrologic, and structural data related to large morphologic features between the Sierra Madre Occidental and the Mexican volcanic belt: Geofísica Internacional, 24, 623-663.

Ramos-Rosique, A., Bryan, S.E., Ferrari, L., López-Martínez, M., Rankin, A., Camprubí, A., Allen, C., Uysal, T., Feng, Y., Reiners, P., 2011, Chronology of mid-Cenozoic magmatism and epithermal mineralization in the Bolaños graben, southern Sierra Madre Occidental, Mexico, in Barra, F., Reich, M., Campos, E., Tornos, F. (eds.), 11th SGA Biennial Meeting - Let's talk ore deposits, Ediciones Universidad Católica del Norte, Antofagasta, Chile, 1, 139-141.

Rossotti, A., Ferrari, L., Martínez-López, M., Rosas-Elguera, J., 2002, Geology of the boundary between the Sierra Madre Occidental and the Trans-Mexican volcanic belt in the Guadalajara region, western Mexico: Revista Mexicana de Ciencias Geológicas, 19, 1-15.

Scheubel, F.R., Clark, K.F., Porter, E.W., 1988, Geology, tectonic environment, and structural controls in the San Martín de Bolaños district, Jalisco, Mexico: Economic Geology, 83, 1703-1720. 
Servicio Geológico Mexicano, 2006a, Carta geológico-minera Hostotipaquillo 1:50,000 F13-D43: Pachuca, Hidalgo, Servicio Geológico Mexicano, Secretaría de Economía.

Servicio Geológico Mexicano, 2006b, Carta geológico-minera El Salvador 1:50,000 F13-D44: Pachuca, Hidalgo, Servicio Geológico Mexicano, Secretaría de Economía.

Snee, L.W., Sutter, J.F., Kelly, W.C., 1988, Thermochronology of economic mineral deposits: Dating the stages of mineralization at Panasqueira, Portugal, by high precision ${ }^{40} \mathrm{Ar} /{ }^{39} \mathrm{Ar}$ age spectrum techniques on muscovite: Economic Geology, 83, 335-354.

Steiger, R.H., Jäger, E., 1977, Subcommission on Geochronology: Convention on the use of decay constants in Geo and Cosmochronology: Earth and Planetary Science Letters, 36, 359-362.
York, D., Evensen, N.M., López-Martínez, M., De Basabe-Delgado, J., 2004, Unified equations for the slope, intercept, and standard errors of the best straight line: American Journal of Physics, 73 (3), 367-375.

Manuscript received: September 1, 2015.

Corrected manuscript received: December 20, 2015.

Manuscript accepted: January 10, 2016. 